\title{
THE INFLUENCE OF ASSETS STRUCTURE ON FINANCIAL PERFORMANCE IN CROATIAN BANKING SYSTEM
}

\author{
Iris LONČAR (D*, Tonći SVILOKOS(D) \\ Department of Economics and Business Economics, University of Dubrovnik, \\ Lapadska obala 7, 20000 Dubrovnik, Croatia \\ *E-mail: iris.loncar@unidu.hr
}

\begin{abstract}
Purpose - as the largest share of national money assets is concentrated in banks, their profitability is important not only for shareholder but also for the whole economy. The aim of this paper is to analyse the influence of the structure of total assets and its liquidity on overall success in the Croatian banking industry.
\end{abstract}

Research methodology - in order to achieve the main purpose the cross-section regression models will be estimated which will include standard profitability indicators and various liquidity and assets indices.

Findings - the results of the analysis show that the level and the structure of total assets, as well as the level of its liquidity, significantly influence its profitability.

Research limitations - the analysis in this paper is limited to the influence of the asset side of the bank balance sheet in cross-section conditions. Therefore this research could be considered as a preliminary one and should be expanded by introducing the other indicators from liability in wider time horizons.

Practical implications - the results outlined in this paper could be practical guidelines for successful asset management which is prerequisite for achieving an adequate financial performance in the banking business.

Originality/Value - according to our knowledge, research of this phenomenon is very rare, so this is one of the first papers considering the impact of asset structure on bank performance for the Croatian banking system.

Keywords: structure of total assets, non-income assets, liquidity, profitability, return on assets, return on equity, the Croatian banking industry.

JEL Classification: M41, G21.

Conference topic: Contemporary Financial Management.

\section{Introduction}

The financial sector has an extremely important impact on the economy. Besides its role in providing payment services, it mobilizes savings, reallocates resources, increases the standard of living, supports firms to reduce risks and costs connected with performing activities, and similar. The well regulated and efficient financial system contributes to the confidence of its participants, which encourage all the subjects with money surpluses to entrust their funds to financial institutions and markets. Through the mobilization of resources, financial systems allow the pooling of capital and its distribution toward different investment projects. In return, investments encourage development and lead to the new money surpluses. King and Levine (1993) have proven that strong domestic financial intermediation promotes the economic growth of the country. Boon (2005) pointed out the existence of controversy: while the supply leading theories consider the development of the financial sector as the precondition for economic growth, the demand following theories consider financial development as merely responsive to economic growth. Anyway, indisputable is that there is a strong connection between financial systems and countries' economic development.

Since it has been shown that the stock and bond markets are underdeveloped in almost all developing countries, and because of that it cannot be expected that they represent a significant source of funds for corporations' and economies' development. Therefore, in these countries, banks have entirely taken over the process of intermediation. The explained situation is also typical for Croatia which is one of the bank-centric countries. The Croatian banking sector is one of the domestic economy's strongest sectors with just 24 banks that were at the end of 2017 operated in the market. Besides, Croatia has one of the highest levels of foreign bank ownership in the world. Due to the strong global influence of banking, it is very important to determine which factors affect the profitability of this sector. In 
this paper, we have limited to the analysis of the influence of the structure of total assets and its liquidity on overall success in the Croatian banking industry.

The organization of the paper is as follows: the first section reviews the theoretical foundation and the existing empirical researches concerning asset structure and financial performance in banking systems. The second section provides an insight into the main structural features of the Croatian financial and banking sector. The third section explains the measurement and data sources and finally, the fourth section results in models and a discussion which is ended by the conclusion.

\section{Literature overview}

Banks' financial performance is a function of a wide range of controllable and uncontrollable factors. Lots of authors have investigated the effects of various factors on the profitability and results of banks. In the first part of this literature review we have articulated the most important papers that investigate this topic worldwide, and in the second part, the main findings of Croatian practice are presented.

Molyneux and Thornton (1992) examined the determinants of bank performances across eighteen European countries between 1986 and 1989. They have estimated a simple linear equation using a pooled sample and they have found the evidence that supports the expense preference expenditure theories, but have not found the evidence for the EdwardsHeggestad-Mingo risk avoidance hypothesis.

Demirgüç-Kunt and Huizinga (2000) have investigated the impact of financial development and structure on bank performance. They have taken into consideration the relative importance of bank-based or market-based finance. According to those criteria, national financial systems can be classified as bank-based or market-based. In bank-based systems, like Japan or Germany, banks play a main role in directing funds from net savers to net borrowers. Although banks are very important participants in the market of the United States and the United Kingdom, the role of non-bank loans, bonds and stocks are more important in the process of financing compared to the same in Japan and Germany. For that reason, mentioned countries are considered as market-based systems. Generally, developing countries are predominantly characterized by a bank-based system. On the contrary, in developed countries, both bank-based and the market-based system can be found, but if the stock market is less developed, the bank margins and profits are higher. Demirgüç-Kunt and Huizinga have also proven that financial structure per se does not have a significant, independent influence on bank profits and margins.

Paper of Naceur (2003) have analysed the impact of bank's characteristics, financial structure and macroeconomic indicators on the bank's net interest margins and profitability in the Tunisian banking industry for the period 1980-2000. He found out that high net interest margin and profitability tend to be associated with banks that hold a relatively high amount of capital. He has proved that bank loans also have a positive and significant impact, while the size has mostly negative and significant coefficients on the net interest margins. The paper concluded that the macro-economic indicators such as inflation and growth rates have no impact on the bank's interest margins and profitability.

Goddard, Molyneux, and Wilson (2004) have studied the profitability of European banks during the 1990s employing cross-sectional, pooled cross-sectional time series and dynamic panel models. They have found the weak evidence for a size-profitability relationship and positive relationship between off-balance-sheet business and profitability for the UK, but either neutral or negative elsewhere. They have also revealed a positive influence of the capital-asset ratio.

Using the ordinary least squares estimation technique, Zhang and Dong (2011) have examined the profitability of the U.S banking sector over the period from 2000-2008. They have found that the bank-specific variables such as capital ratio, loans and deposits are positively related to bank performance as measured by ROA regardless of whether it is small, medium or large banks.

In order to maintain the quality and profitability of their system in a rapidly changing environment, banks should dynamically optimize asset and liability structure. This was especially important during the global financial and European debt crisis. Saksonova (2013) has studied these extraordinary situations and concluded that following management techniques could be useful for maximizing profitability: (a) lowering relative funding costs by increasing the proportion of equity, and by lowering dividends, and (b) diversifying profitable operations by financial innovations.

Trujillo-Ponce (2013) has empirically analysed the main factors that determine the high bank profitability in Spain for the period of 1999-2009, using an unbalanced panel data of 697 observations. He has indicated that high bank profitability is associated with a large percentage of loans in total assets, a high proportion of customer deposits, good efficiency, and low credit risk. Besides, he has found out that better-capitalized banks tend to be more profitable when ROA is taken as the measure of profitability. However, an increase in the equity-to-total-assets ratio reduces the ROE of the banks due to the fall in leverage. Consequently, the high level of capitalization of Spanish banks could have favoured their ROA to the detriment of their ROE.

An unexpected conclusion came from the research which was conducted by Petria, Capraru, and Ihnatov (2015) who have tried to assess the main determinants of banks' profitability in EU27 over the period 2004-2011. They have settled as a proxy for banks profitability the return on average assets (ROAA) and the return on average equity (ROAE) and have concluded that the size of the banks do not have an influence on ROAE and have a small and weak significant effect in the case of ROAA. Simultaneously, they have concluded that credit and liquidity risk, manage- 
ment efficiency, the diversification of business, the competition and economic growth have an influence on bank profitability, both on ROAA and ROAE.

As far as the Croatian banking system is concerned, the paper of Jermić and Vujčić (2002), Jurman (2008) and PejićBach et al. (2009) should be mentioned.

Jermić and Vujčić (2002) have analysed bank efficiency in Croatia between 1995 and 2000 by using the Data Envelopment Analysis (DEA). They found out that:

- foreign-owned banks are, on average, the most efficient,

- new banks are more efficient than old, and

- smaller banks are globally efficient, but large banks are efficient when they allow for variable-returnsto-scale.

Jurman (2008) has concluded that a strong linear positive relationship between bank credit potential and GDP growth could be noticed in Croatia for the period from 1994 to 2007. In line with his findings, the author suggested that banks should change their crediting policy. Credits to the population, as the largest share in crediting, should be significantly slowed down, while financial monitoring of current operations and development of economic subjects should be significantly increased.

Pejić Bach, Posedel, and Stojanović (2009) setup pooled time average model for Croatia. Empirical result of their research has shown that Croatian bank profitability mostly depends on particular characteristics of every particular bank, not so much on other environmental conditions. They have found that capital to assets ratio has a negative influence on ROE, the ratio of net new loans and short term financing has a negative influence on ROA and ratio of non-performing assets and total assets, as well as that market share has positive effects on ROA.

Pervan, Pelivan, and Arnerić (2015) have defined and estimated a model that would enable the identification of the profitability determinants of Croatian banks. The analysis was conducted for the period 2002-2010 and the ROA indicator was used as a dependent variable in the model of bank profitability. The model incorporated three groups of profitability determinants: bank-specific, industry-specific and macroeconomics. Authors have proved that statistically significant variables with a positive influence on Croatian bank profitability are: profitability from the previous year, bank size, solvency risk, intermediation, industry concentration, market growth and GDP growth.

\section{Structure of Croatian financial and banking sector}

The phenomenon of decentralization of intermediation activities, which is prevalent in highly developed countries, is determined by highly specialised firms that emerge as entities that have a narrower scope than banks, but in the same time, they perform an extremely important function. That new model opens up significant opportunities for the development of economies of specialization and assigned a diminished role to the traditional banks (Cetorelly, Mandel, \& Mollineaux, 2012). Unlike described, the so-called "shadow banking" system, the Croatian economy is still familiar with the bank-centred model and traditional, general-purpose banks as central mediators between funding supply and demand. Importance of banks in the Croatian economy is recognized by numerous authors. Jakovčević (2001), for example, states that the banking system's development is directly correlated with the development of the whole economy, because the banks are the main financial service providers of the real sector and they financially support production, consumption and investments, which consequently leads to the improvement of the standard of living of the entire nation. Demirgüç-Kunt, Feyen, and Levine (2011) examined the association between financial structure and economic development and they emphasized some key features. First, they proved that bank development is positively correlated with economic development and secondly, they conclude that financial development involves bigger banks. But, they also stressed that financial systems generally become more market-based during the process of economic development - in other words, as economies grow, securities markets tend to develop more rapidly than banks.

With the aim of clarifying the observed structure of the Croatian financial sector, we have chosen to analyse the changes that have occurred in it over the past 20 years. Figure 1. clearly shows the dominance of banks in the Croatian financial sector during the whole period, although the number of banks was continuously decreased. Until 2000 there were approximately 60 banks in Croatia, while by the end of 2010 there were 32 banks and two saving banks, and at the end of 2017, just 24 banks and one saving bank were performing their activities (Croatian National Bank [CNB], 2011, 2018). Although their number has halved, banks still control the overwhelming majority of the financial sector's total assets.

According to the relative share of the individual bank's assets in total assets value of all banks, banks are usually divided into large, medium-sized and small banks. The group of large banks consists of the banks with total assets value over $5 \%$ of the total assets of all banks, medium-sized banks include banks with assets $1-5 \%$ of the total assets of all banks, and small banks are the banks with assets below $1 \%$ of the total assets of the banks. Classification of Croatian banks according to their size of assets is shown in Table 1. 


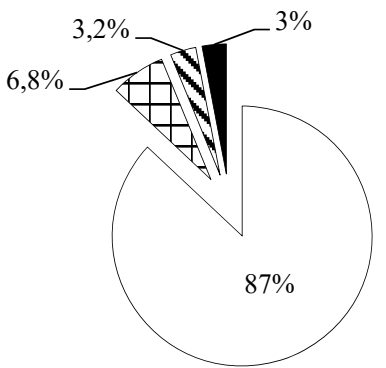

Structure in 2000

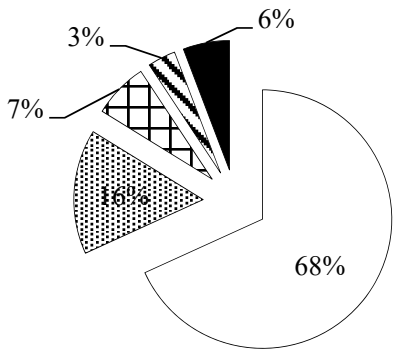

$\square$ Banks

Bin Mandatory pension

funds

$\square$ Insurance companies

Investment funds

- Other subjects

Figure 1. Structure of the Croatian financial sector based on total assets (source: CNB, 2006 \& Croatian Banking Association [CBA], 2018)

Table 1. Structure of Croatian banks according to their size of assets and share in all banks' assets

\begin{tabular}{|l|c|c|c|c|}
\hline \multirow{2}{*}{ Type of banks } & \multicolumn{2}{|c|}{2000.} & \multicolumn{2}{c|}{2017.} \\
\cline { 2 - 5 } & Number of banks & The share of banks (\%) & Number of banks & The share of banks (\%) \\
\hline Large banks & 5 & 11,4 & 8 & 33,3 \\
\hline Medium-sized banks & 13 & 29,5 & 1 & 4,2 \\
\hline Small banks & 26 & 59,1 & 15 & 62,5 \\
\hline Total & 44 & 100,0 & $24 *$ & 100,0 \\
\hline
\end{tabular}

* In the total number of banks (25), 24 banks were performing their activities at 31. of December 2017 and 1 bank was bankrupt (source: CNB, 2001, 2018)

The data illustrates the significant decrease in the number of banks in the last two decades. Theoretically, with regard to decreasing trend, an increase in concentration can be expected and what exactly is confirmed in Croatian practice. According to the published data for 2017, top six Croatian banks hold roughly $80 \%$ of market share by assets, and foreign ownership in the banks is prevailing with $90 \%$ of assets under the control (European Banking Federation [EBF], 2018). Consequently, it can be concluded that small and domestic banks as well, are relatively irrelevant from the aspect of their share in assets of all banks.

In order to examine the concentration of a market, the Herfindahl-Hirschman index (HHI) is commonly used as a representative measure. To calculate this indicator the square sum of market shares of all participants on the market is taken

$$
H H I=\sum_{i=1}^{n} s i^{2}
$$

where: $n$ - the number of banks; $s(i=1$ to $n)$ - market shares.

If market shares are expressed in terms of percentages and if the whole percentages are taken for calculation, HHI can range between 0 and 10.000. In a perfectly competitive market, HHI approaches zero, while in the case of a monopoly, HHI approaches 10.000. According to the definition, a market with HHI between 1.000 and 2.000 points (1.800 is applied in the U.S.) is considered a moderately concentrated market and non-concentrated (fairly competitive) markets are all with HHI lower than 1.000 .

Value of HHI for the Croatian banking sector in the observed period (2000-2017) is between 1.237 and 1.482. It can be concluded that the Croatian banking sector is characterised by an oligopolistic structure: it is polarised into a small number of large banks and a large number of small banks.

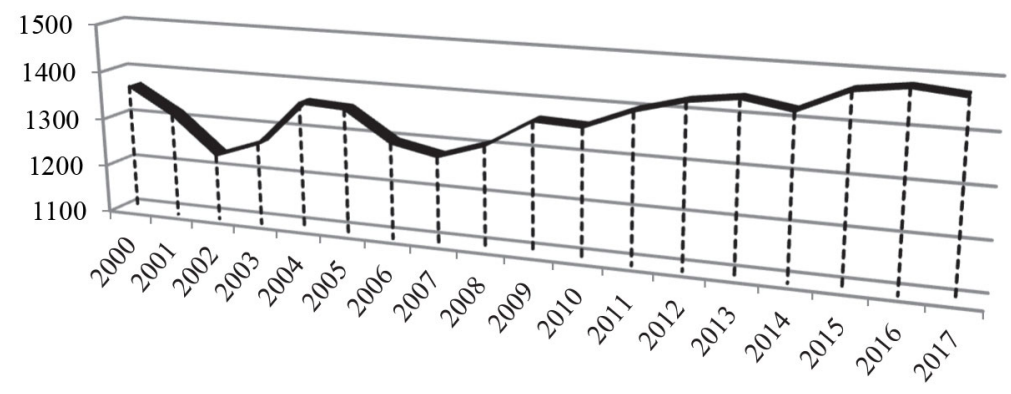

Figure 2. Values of HHI in the Croatian banking market (source: Authors' calculation according to CNB dana) 
It is necessary to keep in mind that high concentration in banking market can have negative effects on the system due to reduced competition, and apart from the fact that banks can form higher prices, there is also a problem of risk dispersion which can be dangerous for the financial stability of the country (Delalić, Čurković, \& Antić, 2018).

The quality of credit exposure improved in the recent period (Table 2). Loans in foreign currencies, including loans in kuna indexed to a foreign currency, decreased in 2017. and just because of mentioned changes in the currency structure of loans, the reduction of bank exposure to currency-induced credit risk was noticeable.

High capitalization is often considered as a guarantee of long-term security. In 2017. in Croatia system level capitalisation at individual bank level was very high, especially in top banks according to the size of their assets. The rates of nine banks, whose assets account for $81.0 \%$ of the system, were higher than $20 \%$.

Table 2. Structure of bank placements in 2017

\begin{tabular}{|c|c|}
\hline \multicolumn{1}{|c|}{ Bank placements } & The share (\%) in total placements \\
\hline Assumed off-balance sheet liabilities & 14.90 \\
\hline Income-based claims & 0.50 \\
\hline Held-to-maturity financial assets & 0.80 \\
\hline Loans and receivables & 83.80 \\
\hline$>$ Deposits & 20.60 \\
\hline$>$ Loans & 61.90 \\
\hline$>$ Debt securities & 0.60 \\
\hline$>$ Other & 0.70 \\
\hline Total & 100.00 \\
\hline
\end{tabular}

Despite the unfavourable profitability trends of Croatian banks in last years, the banking system is still one of the major sectors in Croatian economy and they are definitely leaders in creating new value (in this analysis new value, i.e. value added is calculated as a simple sum of gross wages and gross profit). Although they operated with approximately $40 \%$ lower profits in 2017 in comparison with previous year, banks still produce over one billion Euros of newly created value. According to the research carried out by Lider \& Bisnode (2018) among the top 500 Croatian companies, there are 14 banks, while among the top 10, there are even 3 banks. In terms of value added across sectors, the largest share is held by banks $-10 \%$ and they also remained on top in terms of the profits (their share within the top 500 is $13.6 \%$ ).

Because of banks' importance in financial sector, their contribution to stability, growth and performances of the whole economy, as well as because of all other possible benefits that can be derived from banking sector (for example: financial inclusion of the country, mitigating of risks, encouraging competition ...), the problem of recognition of influencing factors that affect profitability becomes extremely interesting. In this paper, we have chosen to investigate how the structure of assets could reflect on banks' performance. Indirectly, we expect to conclude which possible consequences for the whole economy might outcome regarding the high concentration of this sector.

\section{Methodology, theoretical framework and data}

The starting assumption of following empirical research was that the structure of the asset and its liquidity affects the financial performance of the bank. The earnings capacities and their liquidity position are determined by the quality of assets that banks possess. In order to check the stated assertion, we used data from financial reports obtained from CNB for each of the 24 banks that were operating in the Croatian banking system at the end of 2017. We systemized the key components, mostly from their balance sheets, in order to examine assets' structure and to calculate indicators of profitability and liquidity. Our empirical research resulted in setting up the cross-section models.

According to available literature (Demirgüç-Kunt \& Huizinga, 2000; Pavković, 2004; Albertazzi \& Gambacorta, 2009; Gul, Irshad, \& Zaman, 2011), the commonly used indicators of profitability are: return on assets (ROA) and return on equity (ROE). ROA is ratio which is calculated by dividing the net income of the bank in a given time period with a total value of its assets, and ROE is the ratio of net income and total shareholders' equity. The differences between these indicators appear because of different financial leverage is used. In the situation when a bank uses a lot of equity capital in comparison to the total liability, it will be faced with a relatively large ROA and relatively small ROE at the same time. The same is validated for the reverse case. Usually, in a bank balance sheet, we can notice that the leverage is heavily used.

According to the previously explained banks' classification based on their size, it can be concluded that there are eight large banks in Croatia, and only two of them account for $45.5 \%$ of the market, while all large banks make $90.5 \%$ of the banking market. Weighted average ROA for large banks is $0.9975 \%$ and for small banks, it is $-0.175 \%$. Weighted average ROA for the whole banking system is $0.8555 \%$. Only one large bank make a loss in 2017 , while seven out of 15 small banks have a negative result. Weighted average ROE for the large banks is $15.52 \%$. 
Table 3. Profitability, market shares and leverage of Croatian banks in 2017

\begin{tabular}{|c|c|c|c|c|c|}
\hline Bank & ROA & ROE & $\begin{array}{l}\text { The share of the } \\
\text { bank's assets in the } \\
\text { Banking system }\end{array}$ & $\begin{array}{l}\text { The share of the } \\
\text { bank's equity in the } \\
\text { Banking system }\end{array}$ & $\begin{array}{c}\text { The share of } \\
\text { equity in total } \\
\text { liabilities }\end{array}$ \\
\hline ADDIKO & 0.010833 & 0.089747 & $5.42 \%$ & $7.44 \%$ & $12.07 \%$ \\
\hline KOVANICA & 0.004635 & 0.049625 & $0.29 \%$ & $0.31 \%$ & $9.34 \%$ \\
\hline CROATIA & -0.01228 & -0.06454 & $0.64 \%$ & $1.38 \%$ & $19.03 \%$ \\
\hline ERSTE & 0.011354 & 0.185551 & $14.62 \%$ & $10.18 \%$ & $6.12 \%$ \\
\hline HPB & 0.000421 & 0.00686 & $5.06 \%$ & $3.53 \%$ & $6.14 \%$ \\
\hline IMEX & -0.00812 & -0.0961 & $0.45 \%$ & $0.43 \%$ & $8.45 \%$ \\
\hline IKB & 0.007801 & 0.161382 & $0.86 \%$ & $0.47 \%$ & $4.83 \%$ \\
\hline JIT & -0.02278 & -0.09467 & $0.33 \%$ & $0.89 \%$ & $24.06 \%$ \\
\hline JADRANSKA & -0.01793 & -0.62002 & $0.44 \%$ & $0.15 \%$ & $2.89 \%$ \\
\hline KABA & 0.003516 & 0.043407 & $0.56 \%$ & $0.51 \%$ & $8.10 \%$ \\
\hline KENT & 0.00252 & 0.018841 & $0.53 \%$ & $0.81 \%$ & $13.37 \%$ \\
\hline KREDITNA & 0.006138 & 0.085382 & $0.85 \%$ & $0.71 \%$ & $7.19 \%$ \\
\hline OTP & 0.002656 & 0.012542 & $5.02 \%$ & $12.10 \%$ & $21.18 \%$ \\
\hline PARTNER & 0.003795 & 0.076308 & $0.46 \%$ & $0.26 \%$ & $4.97 \%$ \\
\hline PODRAVSKA & 0.004304 & 0.052108 & $0.84 \%$ & $0.79 \%$ & $8.26 \%$ \\
\hline PRIMORSKA & -0.01596 & -0.12941 & $0.15 \%$ & $0.20 \%$ & $12.33 \%$ \\
\hline PBZ & 0.019022 & 0.415131 & $19.39 \%$ & $10.11 \%$ & $4.58 \%$ \\
\hline RBA & 0.012605 & 0.108876 & $8.02 \%$ & $10.57 \%$ & $11.58 \%$ \\
\hline SAMOBORSKA & -0.01502 & -0.14319 & $0.12 \%$ & $0.14 \%$ & $10.49 \%$ \\
\hline SBER & -0.01527 & -0.08873 & $2.27 \%$ & $4.45 \%$ & $17.20 \%$ \\
\hline SLATINSKA & 0.000407 & 0.007062 & $0.41 \%$ & $0.27 \%$ & $5.77 \%$ \\
\hline SPLITSKA & -0.00316 & -0.06019 & $6.87 \%$ & $4.10 \%$ & $5.24 \%$ \\
\hline VENETO & -0.01326 & -0.02478 & $0.29 \%$ & $1.78 \%$ & $53.53 \%$ \\
\hline ZABA & 0.008214 & 0.085869 & $26.11 \%$ & $28.42 \%$ & $9.57 \%$ \\
\hline
\end{tabular}

Source: author's calculation according to CNB (2018) data.

In general, the Croatian banking system is highly capitalized. In average, large banks have $8.39 \%$ of the equity in regards to their total liabilities. For small banks, that share is even higher and amounts $11.08 \%$.

Table 3 contains the values of ROA and ROE for Croatian banks and their market shares measured by the share of each bank's assets/equity into the total banks' assets/equity, as well as information of leverage used by each bank.

In following models, ROA and ROE were used as the dependent variable and their values are attempted to explain by the set of independent variables that have been calculated from the data presented in banks' balance sheets. In line with the existing researches, the selected variables were used:

$-M-$ market share of the bank measured by the share of banks' assets in total banking assets

- L_A - the ratio of the loan and bank assets

-E_P - the ratio of equity and total liabilities

$-\overline{D E P}_{-} \mathrm{A}-$ the ratio of other deposits and total assets

$-\mathrm{C}_{-} \mathrm{A}-$ the ratio of cash and total assets

- T_A - the ratio of tangible (non-performing) assets and total assets

-GUAR_A - the ratio of given guarantees and total assets

Descriptive statistics for the chosen variables are presented in Table 4.

Our cross-section multiple regression models are:

$$
\begin{gathered}
Y_{i}=\alpha_{1}+\beta_{1} M_{i}+\beta_{2} L_{-} A_{i}+\beta_{3} E_{-} P_{i}+\beta_{4} D E P_{i}+u_{i}, \\
Y_{i}=\alpha_{1}+\beta_{1} M_{i}+\beta_{2} L_{-} A_{i}+\beta_{3} E_{-} P_{i}+\beta_{4} D E P_{i}+\beta_{5} C_{-} A_{i}+u_{i}, \\
Y_{i}=\alpha_{1}+\beta_{1} M_{i}+\beta_{2} L_{-} A_{i}+\beta_{3} E_{-} P_{i}+\beta_{4} D E P_{i}+\beta_{5} T_{-} A_{i}+u_{i},
\end{gathered}
$$




$$
Y_{i}=\alpha_{1}+\beta_{1} L_{-} A_{i}+\beta_{2} E_{-} P_{i}+\beta_{3} E D P_{i}+\beta_{4} G U A R_{i}+u_{i},
$$

were $Y_{i}$ represents dependent variables ROA and ROE.

So, for each model, we calculated two equations presented in the following section. Table 4 contains descriptive statistics for chosen variables.

Table 4. Descriptive statistics

\begin{tabular}{|c|c|c|c|c|}
\hline & Mean & Maximum & Minimum & Std. Dev. \\
\hline M & 0.041667 & 0.261127 & 0.001199 & 0.067759 \\
\hline L_A & 0.511703 & 0.711915 & 0.152383 & 0.121944 \\
\hline E_P & 0.119289 & 0.535257 & 0.028914 & 0.104364 \\
\hline DEP_A & 0.05299 & 0.137676 & 0.01078 & 0.039279 \\
\hline C_A & 0.019261 & 0.06537 & 0.005517 & 0.011718 \\
\hline T_A & 0.01812 & 0.051463 & 0.00343 & 0.010996 \\
\hline GUAR_A & 0.029656 & 0.077876 & 0.000486 & 0.020111 \\
\hline ROA & -0.001065 & 0.019022 & -0.022781 & 0.011311 \\
\hline ROE & 0.00321 & 0.415131 & -0.62002 & 0.17898 \\
\hline
\end{tabular}

Source: author's calculation

\section{Model results and discussion}

Our descriptive analysis shows that most variations can be found in ROE, ROA, and M variables. When we do not take into account the value of assets, the average ROA becomes even negative. The highest ROE is $41.5 \%$, and highest ROA is $1.9 \%$. The minimum market share that controls the smallest bank is $0.1199 \%$, and the biggest bank controls $26.11 \%$ of the market, which we already discussed previously. In average, banks have $51.17 \%$ of loans, $5.3 \%$ of other deposits, $1.9 \%$ of cash, and $1.8 \%$ of tangible assets in total assets. A bank that uses the biggest financial leverage has $2.8 \%$ of the equity in total liability. There is one bank that has even $53.5 \%$ of the equity in total liability which is very uncommon in the banking business.

Our model results indicate that variables L_A and DEP_A are significant in all models. The number of bank loans in total assets positively influence on bank performance, while the ratio of other deposits and bank assets has a negative influence. Variables C_A, T_A, and GUAR_A were not significant, and according to that, we can conclude that quantity of cash, intangible assets and given guarantees in total assets are not important for achieving good banking performance.

In addition, a variable that represents bank market position was significant in model one, two and partially in model three (in the case when we use ROE as the dependent variable). A positive value of the coefficient of variable M is in line to the results of previous research (Simatele et al., 2018; Mirzaei et al., 2013; Pejić Bach et al., 2009).

Table 5. Cross-section models of multiple linear regression

\begin{tabular}{|c|c|c|c|c|c|c|c|c|}
\hline & \multicolumn{2}{|c|}{ Model 1} & \multicolumn{2}{|c|}{ Model 2} & \multicolumn{2}{|c|}{ Model 3} & \multicolumn{2}{|c|}{ Model 4} \\
\hline & \multicolumn{2}{|c|}{ Dependent variables } & \multicolumn{2}{|c|}{ Dependent variables } & \multicolumn{2}{|c|}{ Dependent variables } & \multicolumn{2}{|c|}{ Dependent variables } \\
\hline & ROA & ROE & ROA & ROE & ROA & ROE & ROA & ROE \\
\hline $\mathrm{c}$ & $\begin{array}{c}-0.00824 \\
(-1,01422)\end{array}$ & $\begin{array}{c}-0.1984 \\
(-1.35995)\end{array}$ & $\begin{array}{c}-0.01046 \\
(-1.30717)\end{array}$ & $\begin{array}{l}-0.24181^{*} \\
(-1.72989)\end{array}$ & $\begin{array}{c}-0.00838 \\
(-0.91837)\end{array}$ & $\begin{array}{c}-0.20982 \\
(-1.36216)\end{array}$ & $\begin{array}{l}-0.011288 \\
(-1.33025)\end{array}$ & $\begin{array}{c}-0.25466 \\
(-1.71876)\end{array}$ \\
\hline M & $\begin{array}{c}0.05286^{* *} \\
(2.08310)\end{array}$ & $\begin{array}{c}0.77952 * \\
(1.71163)\end{array}$ & $\begin{array}{c}0.05158^{* *} \\
(2.09930)\end{array}$ & $\begin{array}{l}0.79488^{*} \\
(1.91298)\end{array}$ & & $\begin{array}{c}0.91095^{*} \\
(1.90843)\end{array}$ & & \\
\hline L_A & $\begin{array}{c}0.03074 * * \\
(2.08095)\end{array}$ & $\begin{array}{c}0.55259 * * \\
(2.08393)\end{array}$ & $\begin{array}{c}0.02773 * \\
(1.92058)\end{array}$ & $\begin{array}{c}0.47419^{*} \\
(1.95432)\end{array}$ & $\begin{array}{c}0.04398 * * * \\
(3.046170\end{array}$ & $\begin{array}{c}0.49316^{*} \\
(1.87443)\end{array}$ & $\begin{array}{c}0.036044 * * \\
(2.31235)\end{array}$ & $\begin{array}{c}0.56375 * * \\
(2.11955)\end{array}$ \\
\hline E_P & $\begin{array}{c}-0.04781 * * * \\
(-3.08254)\end{array}$ & $\begin{array}{c}-0.24005 \\
(-0.75458)\end{array}$ & $\begin{array}{l}-0.0413^{* *} \\
(-2.64228)\end{array}$ & & $\begin{array}{c}-0.05838^{* * *} \\
(-3.63495)\end{array}$ & & $\begin{array}{c}-0.05274 * * * \\
(-3.24871)\end{array}$ & \\
\hline DEP_A & $\begin{array}{c}-0.09535^{* *} \\
(-2.31322)\end{array}$ & $\begin{array}{c}-1.67175^{* *} \\
(-2.25971)\end{array}$ & $\begin{array}{l}-0.1141 * * \\
(-2.73188)\end{array}$ & $\begin{array}{c}-2.0267 * * \\
(-2.7754)\end{array}$ & $\begin{array}{c}-0.09892 * * \\
(-2.19722)\end{array}$ & $\begin{array}{c}-1.64095^{* *} \\
(-2.15708)\end{array}$ & $\begin{array}{c}-0.09762 * * \\
(-2.20275)\end{array}$ & $\begin{array}{l}-1.7117^{* *} \\
(-2.20475)\end{array}$ \\
\hline C_A & & & $\begin{array}{l}0.209151 \\
(1.51223)\end{array}$ & $\begin{array}{c}3.97991 \\
(1.70884)\end{array}$ & & & & \\
\hline
\end{tabular}


End of Table 5

\begin{tabular}{|c|c|c|c|c|c|c|c|c|}
\hline & \multicolumn{2}{|c|}{ Model 1} & \multicolumn{2}{|c|}{ Model 2} & \multicolumn{2}{|c|}{ Model 3} & \multicolumn{2}{|c|}{ Model 4} \\
\hline & \multicolumn{2}{|c|}{ Dependent variables } & \multicolumn{2}{|c|}{ Dependent variables } & \multicolumn{2}{|c|}{ Dependent variables } & \multicolumn{2}{|c|}{ Dependent variables } \\
\hline & ROA & ROE & ROA & ROE & & ROA & ROE & ROA \\
\hline $\mathrm{T}_{-} \mathrm{A}$ & & & & & $\begin{array}{l}-0.164756 \\
(-1.07814)\end{array}$ & $\begin{array}{c}0.53417 \\
(0.19242)\end{array}$ & & \\
\hline GUAR_A & & & & & & & $\begin{array}{c}0.109372 \\
(1.228273)\end{array}$ & $\begin{array}{c}2.02654 \\
(1.32897)\end{array}$ \\
\hline ADJ R ${ }^{2}$ & 0.580816 & 0.460640 & 0.607406 & 0.60222 & 0.51476 & 0.44556 & 0.522960 & 0.415267 \\
\hline AIC & -6.812457 & -1.037405 & -6.848724 & -1.150844 & -6.666136 & -1.00982 & -6.683165 & -0.988673 \\
\hline DW & 1.984980 & 2.06826 & 1.424248 & 1.94265 & 1.899121 & 2.02927 & 2.037493 & 2.186528 \\
\hline F-statistic & 8.967140 & 5.910775 & 8.116944 & 7.191387 & 7.099976 & 5.620759 & 7.303491 & 6.444720 \\
\hline
\end{tabular}

Notes: * denotes significance at the level of $10 \%$; * denotes significance at the level of $5 \%$; ** denotes significance at the level of $1 \%$; $\mathrm{t}$ statistics are in parentheses (source: Authors' calculation)

The coefficient of variable L_A usually has a very high significance level, and always a positive sign in all our models. These results are in line with Demirguc (2000) and with Saksonova (2013). A variable that represents equity divided by total liability has a negative sign in all models. This means that, when a bank uses more equity for its financing, it can expect to achieve worse financial results measured by ROE and ROA. This result is in line with Berger (1995) and Spathis (2002). It seems that if a bank increases other deposits, this will have a negative influence on its performance. This can be explained with the fact that these deposits are not the best bank investment choice and today it does not bring a satisfactory return for the bank. According to that this negative sign could be expected. The similar result we can find in Ekpo and Mbobo (2016) and Saksonova (2011).

According to adjusted $\mathrm{R}^{2}$ and value of Akaike information criterion (AIC) the best model in Table 5 is:

$$
R O A_{i}=-0,01+0,0516 M_{i}+0,0277 L_{-} A_{i}-0,0413 E_{-} P_{i}-0,114 D E P_{i}+0,209 C_{-} A_{i}+u_{i} .
$$

This means the following:

- if the bank market share increase for $1 \%$ ROA will increase for 0.0516 percentage points

- if bank increase the share of loans in its assets for $1 \%$ ROA will increase for 0.0277 percentage points

- if bank decrease the quantity of equity that it use compared to total assets for $1 \%$ ROA will increase for 0.0516 percentage points

- if bank decrease the share of other deposits in total assets for 1\% ROA will increase for 0.114 percentage points

- In this model Cash to assets was not significant

With this model, we explained $60.74 \%$ of the ROA variability.

\section{Conclusions}

Under the conditions of a bank-based financial system where banks control the largest part of the financial system, where banks take the highest positions on the list of top 500 companies, and where banks produce over one billion Euros of newly created value, it is of great importance to recognise the determinants of their profitability. This paper investigates the asset structure and the impact of its composition on bank profitability employing cross-section regression models.

The indicative results of this research could be of great help for the decision-maker in bank asset management and in a process of making other bank decisions, such as decisions about the incensement of total assets, or similar. Namely, our models suggest that the bank's profitability will increase if the bank manages to increase its market share. This advocates further consolidations and mergers of banks and thus the further reduction of the number of banks in Croatia. Moreover, it is suggested that the bank should try to increase the share of bank loans in total assets, to reduce the share of other deposits in total assets, and to reduce the ratio of capital to total liability. Of course, these changes have to be made in the context of acceptable risks that also must be taken into account.

The advantage of this research is that it was not conducted based on some sample, but it includes all active banks in Croatia at the end of 2017, and the shortfall is that includes a relatively short series. For a more realistic picture, further research can be focused on using data for various years and on that way employing a panel approach. This changes in the model also require that the list of explanatory variables should be extended with the control variables that will describe the given state of macroeconomic conditions that banks are faced with in different time periods, such as GDP per capita, domestic product growth rate, inflation rate and similar. 


\section{References}

Boon, T. K. (2005). Do commercial banks, stock market and insurance market promote economic growth? An analysis of the Singapore Economy (Working paper of the School of Humanities and Socal Studies). Singapore: Nanyang Technological University.

Cetorelly, N., Mandel, B. H., \& Mollineaux, L. (2012). The evolution of banks and financial intermediation: Framing the analysis. Economic Policy Review, 18(2), 1-12. Retrieved from https:/www.newyorkfed.org/research/economists/medialibrary/media/ research/epr/2012/EPRvol18n2.pdf

Croatian Banking Association [CBA]. (2018). Brochure 2018, 10(21). Retrieved from Croatian Banking Association website: http://www.hub.hr/sites/default/files/doprinos_banaka_en.pdf

Croatian National Bank [CNB]. (2001). Banks Bulletin, 1(2), Retrieved from Croatian National Bank website: https://www.hnb.hr/documents/20182/122059/ebilten-o-bankama-2.pdf

Croatian National Bank [CNB]. (2006). Macroprudential Analysis, 2(4). Retrieved from http://old.hnb.hr/publikac/makrobonitetna-analiza/e-mba-04.pdf

Croatian National Bank [CNB]. (2011). Banks Bulletin, 10(21). Retrieved from Croatian National Bank website: https://www.hnb.hr/documents/20182/121693/ebilten-o-bankama-21.pdf

Croatian National Bank [CNB]. (2018). Banks Bulletin, 18(31). Retrieved from Croatian National Bank website: https://www.hnb.hr/documents/20182/2561265/ebilten-o-bankama-31.pdf

Delalić, A., Čurković, M., \& Antić, J. (2018). The Croatian banking system total assets concentration dynamics: performing a variety of inequality measures. Croatian Review of Economic, Business and Social Statistics, 4(1), 14-26. https://doi.org/10.2478/crebss-2018-0002

Demirgüç-Kunt, A., \& Huizinga, H. (2000). Financial structure and bank profitability (Policy Research Working Paper 2430). Washington, DC: World Bank. Retrieved from https://openknowledge.worldbank.org/bitstream/handle/10986/21368/wps2430.pdf

Demirgüç-Kunt, A., Feyen, E., \& Levine, R. (2011). The evolving importance of banks and securities markets (Policy Research Working Paper 5805). Washington, DC: World Bank. https://doi.org/10.1596/1813-9450-5805

European Banking Federation [EBF]. (2018). Banking in Europe: EBF Facts \& Figures 2018. Retrieved from European Banking Federation website: https:/www.ebf.eu/wp-content/uploads/2018/09/Banking-in-Europe-2018-EBF-Facts-and-Figures.pdf

Goddard, J., Molyneux, P., \& Wilson, J. O. (2004). The profitability of European banks: a cross-sectional and dynamic panel analysis. The Manchester School, 72(3), 363-381. https://doi.org/10.1111/j.1467-9957.2004.00397.x

Jakovčević, D. (2001). Bankovni potencijali, poslovna spajanja banaka i razvitak hrvatskog gospodarstva. Ekonomski pregled, 52(11-12), 1283-1302.

Jemrić, I., \& Vujčić, B. (2002). Efficiency of banks in Croatia: A DEA approach. Comparative Economic Studies, 44(2-3), 169193. https://doi.org/10.1057/ces.2002.13

Jurman, A. (2009). Financial potential of Croatian banks, characteristics and growth projection. Economic research-Ekonomska istraživanja, 22(1), 60-80. Retrieved from https://hrcak.srce.hr/index.php?id_clanak_jezik=60034\&show=clanak

King, R. G., \& Levine, R. (1993). Finance, entrepreneurship, and growth: Theory and evidence. Journal of Monetary Economics, 32(3), 513-542. https://doi.org/10.1016/0304-3932(93)90028-E

Lider \& Bisnode. (2018) 500 najboljih; 500 najvećih stvaratelja nove vrijednosti u Hrvatskoj 2017 (Posebno izdanje). Zagreb, Croatia: Lider media d.o.o.

Molyneux, P., \& Thornton, J. (1992). Determinants of European bank profitability: A note. Journal of Banking \& Finance, 16(6), 1173-1178. https://doi.org/10.1016/0378-4266(92)90065-8

Naceur, S. B. (2003). The determinants of the Tunisian banking industry profitability: Panel evidence (Working paper of the Université Libre de Tunis). Tunis: L'Université Libre de Tunis.

Pejić Bach, M., Posedel, P., \& Stojanović, A. (2009). Determinante profitabilnosti banaka u Hrvatskoj. Zbornik ekonomskog fakulteta u Zagrebu, 7(1), 81-92. Retrieved from https://hrcak.srce.hr/40546

Pervan, M., Pelivan, I., \& Arnerić, J. (2015). Profit persistence and determinants of bank profitability in Croatia. Economic Research-Ekonomska Istraživanja, 28(1), 284-298. https://doi.org/10.1080/1331677X.2015.1041778

Petria, N., Capraru, B., \& Ihnatov, I. (2015). Determinants of banks profitability: evidence from EU 27 banking system, Procedia Economics and Finance, 20, 518-524. https://doi.org/10.1016/S2212-5671(15)00104-5

Saksonova, S. (2011). Approaches to determining optimal asset structure for a commercial bank. International Journal of Economics and Management Engineering, 5(5), 588-594. Retrieved from https://waset.org/publications/7576/approaches-todetermining-optimal-asset-structure-for-a-commercial-bank

Trujillo-Ponce, A. (2013). What determines the profitability of banks? Evidence from Spain, Accounting and Finance, 53(2), 561586. https://doi.org/10.1111/j.1467-629X.2011.00466.x

Zhang, C., \& Dong, L. (2011). Determinants of bank profitability: Evidence from the U.S. Banking Sector (Research project, FRM Project-Simon Fraser University). Vancouver, CA: Segal Graduate School of Business. Retrieved from http://summit.sfu.ca/item/13065 